\title{
An Analysis of Digital Leadership in the Pandemic Covid-19 Era
}

\author{
Fujy Puspita Damayanti*, Aceng Muhtaram Mirfani \\ Educational Administration Department, School of Postgraduate \\ Universitas Pendidikan Indonesia \\ Bandung, Indonesia \\ *fujydamayanti@upi.edu
}

\begin{abstract}
The development of technology globally and spread of Coronavirus Disease (Covid-19) around Indonesia has necessitated social distancing measures to minimize the disease dissemination. Along with this deal, it is necessary to have a leader's role in face this problem. This research addressed to identify the process of digital leadership by the leader in order to lead, support and manage the school by the utilizing of technology during pandemic covid19. Accordingly, a qualitative research design using questionnaires and semi-structured interviews were employed to collect the research data. A closeended questionnaire was administered to the teachers, staff, and students of MA Nurul Falah to identify their opinion about implementing digital leadership and how it's reflected in the new education system during pandemic covid-19. Furthermore, researchers have conducted a semi-structured interview to look deep into the data in this research. This research showed that most of the participants' size up that digital leadership in MA Nurul Falah was lower. In conclusion, based on the questionnaire and interviews, the role of leader and digital leadership implementation significantly affected to the management and learning activities in MA Nurul Falah.
\end{abstract}

Keywords—digital leadership, management, pandemic Covid-19

\section{INTRODUCTION}

Since the World Health Organization (WHO) determined that the spread of the coronavirus (Covid-19) to be a contagious disease, it has become a serious problem and caused a global pandemic. Therefore, somebody cannot stop its spread throughout the world. Globally, current data released by the Indonesian National Board for Disaster Management on Wednesday, September 23, 2020, it showed that 257,3888 confirmed, 187,958 recovered, and 9,837 passed away [1]. This Pandemic is a massive challenge to many aspects such as health, economy, social, culture, and education in Indonesia. Apart from this, as stated above, the implementation of education needs social distancing, and it takes place without having to contribute new cases in the spread.

Besides, it is in line with changes and developments globally; technology has evolved a lot. It is known that recently about the concept of the Industrial revolution 4.0. the rapid growth of internet use. The world economic forum can say that this is the era that we are entering now, where advances in information technology dominate the joint human life. The internet, data, and artificial intelligence are a line of technologies that are supporting this revolution. Japan has reached the 5.0 civilization revolution in which, through the Society 5.0, artificial intelligence will transform big data in all aspects of life. This transformation will help humans to live a more meaningful life. Society 5.0 In simple terms, we can define Society 5.0 as a concept of a human-centered and technology-based company [2].

Consequently, in this global world in which educational technologies have developed at such a high space, it is possible to say that administrators in the education sector are obliged with serious roles concerning keeping up with the evolving technology and the management of education in this virtual and pandemic environment need the part of digital leadership. The success of an organisation, like a school, largely depends on the quality of the decisions made by their leaders [3]. It's also supported by Goethals et al. in 2002 that digital leadership means leadership in the core sectors of the information society, such as communication, press, or multiple media. However, both leadership styles are very similar to each other; and both benefit from core ICT sectors to link customers and suppliers. Therefore, today, all leaders (in the field of health, art, or production) should be aware of the new restrictions and opportunities provided by ICTs and use them effectively [4].

Previous literature on leadership and technology shown that there is moderate correlation between both transactional and transformational leadership styles. It is concluded that leadership style is not a predictor of competency level of technology leadership. The study contributes into literature discussing the effects of cultural differences in different countries on desired leadership styles, which in result may effected to the level of technology leadership competency [5]. Besides, from the digitalization and digital transformation literature, it can be shown that leadership and incorporation of the concept of leadership practice strengthens the original organizational learning framework on all levels in the school organization. The conceptual model integrates and improves theoretical frameworks for context-conscious, organizational learning and distributed leadership [6]. However, previous 
literature has not yet examined the implication of digital leadership in the pandemic covid19. Therefore, this research addressed to set out the concepts and explore the concept of digital leadership and how it's reflected in the new education system during pandemic covid-19 and the aspects of digital leaders through literature review.

\section{LITERATURE REVIEW}

\section{A. Corona Virus Diseases}

Coronavirus is one of the major pathogens that primarily targets the human respiratory system. Previous outbreaks of coronaviruses (CoVs) include the severe acute respiratory syndrome (SARS)-CoV and the Middle East respiratory syndrome (MERS)-CoV which have been previously characterized as agents that are a great public health threat. In late December 2019, a cluster of patients was admitted to hospitals with an initial diagnosis of pneumonia of an unknown etiology. These patients were epidemiologically linked to a seafood and wet animal wholesale market in Wuhan, Hubei Province, China [7].

Covid-19 has become something terrible since the start of 2020. The spread of the virus so fast and massive make many countries in this world overwhelmed to face this global pandemic. Apart from the fatal human casualties and the disruption of millions of human lives, education problems occur significantly. In the face of particular challenges and an uncertain set of risks, education leaders and stakeholders are concerned about how their education will be affected and what they should do next. The Covid-19 pandemic will likely accelerate the inevitable fundamental and structural changes in any case. Everything happened much faster than it should have. Consider that the "virtualization" of work is done from home or elsewhere, with collaboration and distance learning policies and travel reduction for physical encounters having been steadily developing. Today, all over the world, businesses are learning to communicate, collaborate, and coordinate on virtual platforms, and understand the increased efficacy and efficiency that these work modalities can provide. Virtual work and collaboration tools are likely to create new, booming market spaces [4]. The spread of the virus so fast and massive make many countries in this world overwhelmed to face this global pandemic. Apart from the fatal human casualties and the disruption of millions of human lives, education problems occur significantly. Therefore, this case needs a guidance from the teachers, institutional heads, and officials on addressing the crisis.

\section{B. The Concept of Digital Leadership}

Along with the increase of corona cases and the development of useful technology, it is necessary to have a leader who can adapt to the era of the Covid-19 pandemic crisis and the period of society 5.0. As stated by Leithwood et al. in 2010, leadership has played an essential role in complex causal models of educational effectiveness and school improvement. The suitable here is digital leadership or in other words called as virtual leader. In the 2010 Kerfoot said that virtual leadership as leading an organization that is other than physical. In other words, it is the management of distributed work teams whose members predominantly communicate and coordinate their work through electronic media [8]. It also supported by Zigurs on 2003 he was defines that virtual team are individuals who are geographically and/or organizationally or otherwise dispersed and who collaborate via communication and information technologies in order to accomplish a specific goal [9].

Digital Leadership is one of the solutions. Someone who has the ability in the use of technology and digitalization will takes into account recent changes such as ubiquitous connectivity, open-source technology, mobile devices, and personalization, it represents a dramatic shift from how schools have been run and structured for over a century [10]. What started as personal use of technology has become systemic to every facet of leadership. Based on Larjovuori et al. in the 2016 defined digital leadership as the leaders' ability to create a clear and meaningful vision for the digitalization process and the capability to execute strategies to actualize it [11]. Because being leader, someone is not only lead the organization but also as a person who has a duty become a managers that should control human, focus to the resources tangible and intangible and the last as administrators who deal with day-to-day operational matters, and continuously shift between leadership and management functions. In conclusion, digital leadership can thus be defined as establishing direction, influencing others, and initiating sustainable change through the access of information, and establishing relationships to anticipate changes pivotal to school success in the future. It requires a dynamic combination of mindset, behaviour, and skills employed to change and or enhance school culture through the assistance of technology.

\section{RESEARCH METHODS}

Researchers employed the qualitative method in a particular case study. According to Creswell 1998 qualitative research is an inquiry process of understanding based on distinct methodological traditions of inquiry exploring a social or human problem [11]. This research was applied case study, and the questionnaire was distributed during the Pandemic in MA Nurul Falah. This research also was used semi-structured to conduct an in-depth explanation concerning the construct of digital surveillance and explore participants' perceptions of diversity and leadership overall and look for how digital guidance during pandemic reflection in education at MA Nurul Falah. Concerning digital leadership, interviewees define it overall as leadership in times of digital transformation.

\section{A. Research Instruments}

1) Questionnaire: The aspects of questionnaire relate to the digital leadership are in table 1 as follows: 
TABLE I. THE ASPECTS OF EACH NUMBER QUESTIONNAIRE ABOUT DIGITAL LEADERSHIP AND MANAGEMENT IN EDUCATION

\begin{tabular}{|l|l|}
\hline \multicolumn{1}{|c|}{ No. } & \multicolumn{1}{c|}{ Aspects } \\
\hline $1-5$ & Leadership and vision dimension \\
\hline $6-10$ & Learning and teaching dimension \\
\hline $11-16$ & Productivity and professional practice dimension \\
\hline $17-20$ & Support, management, and operations dimension \\
\hline $21-25$ & Assessment and evaluation dimension \\
\hline
\end{tabular}

\section{2) Interviews}

TABLE II. THE CODE OF EACH NUMBER INTERVIEW'S LIST S ABOUT DIGITAL LEADERSHIP AND MANAGEMENT IN EDUCATION

\begin{tabular}{|l|l|}
\hline \multicolumn{1}{|c|}{ No. } & \multicolumn{1}{c|}{ Code } \\
\hline $1,6,9,10$ & Leadership and vision dimension \\
\hline $2,3,8$ & Learning and teaching dimension \\
\hline $4,5,7$ & Productivity and professional practice dimension \\
\hline 10,12 & Support, management, and operations dimension \\
\hline $13,14,15$ & Assessment and evaluation dimension \\
\hline
\end{tabular}

\section{B. Data Collecting Technique}

Data collected from the results of questionnaires were processed using Weighted Means Scored (WMS) i.e. percentage by weighting. The results of data processing are then validated by the interview method using purposive sampling.

\section{Research Site and Participant}

This research was conducted in MA Nurul Falah, Tasikmalaya Regency, West Java Province. The participants of this research were the teachers, students and staffs of MA Nurul Falah by using purposive sampling.

\section{RESULTS AND DISCUSSION}

Close-ended questionnaire was first instrument that applied in this research. It was used to identify the implementation of digital leadership by the leader in MA Nurul Falah. The questionnaire was distributed to the teachers, staff and students of MA Nurul Falah. The data analysis showed that digital leadership on that institution had low digital leadership. It can be seen on the table as follows :

TABLE III. PARTICIPANTS' SCORE ON DIGITAL LEADERSHIP

\begin{tabular}{|l|l|l|}
\hline $\begin{array}{c}\text { Level of Digital } \\
\text { Leadership }\end{array}$ & \multicolumn{1}{c|}{$\begin{array}{c}\text { Number of } \\
\text { Participants }\end{array}$} & Percentage \\
\hline Low & 12 & $88 \%$ \\
\hline Neutral & 2 & $8 \%$ \\
\hline High & 1 & $4 \%$ \\
\hline
\end{tabular}

Researchers will elaborate on the findings and discussion of each aspect of the implementation of digital leadership further.

\section{A. Leadership and Vision Dimension}

The data analysis showed that most of the participants agree that their leader was right to lead the school, but in the utilizing of technology in order giving instruction, decision making the leader was still lower. The data below shows the tabulation of the finding.

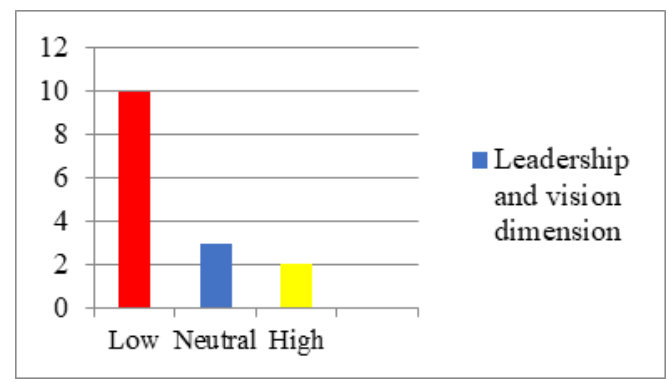

Fig. 1. Questionnaire Leadership and vision dimension.

\section{B. Learning and teaching dimension}

Concerning the learning and teaching dimension, each statement's average answer was neutral found. Teachers said that the implementation of teaching-learning in MA Nurul Falah sometimes uses technology such as Gmail, google meet, zoom cloud meeting, and WhatsApp group. The response from the teacher also supports it. They agree that using if technology were neutral.

\section{Productivity and professional practice dimension}

Based on the questionnaire's findings, the participants said that the implementation of digitalization in their school had low because only some participants who can maximize the use of technology.

\section{Support, management, and operations dimension}

The participants' perception possessed a low command of digital leadership concerning the questionnaire data about support, management, and operations. It can be seen in the chart as follows.

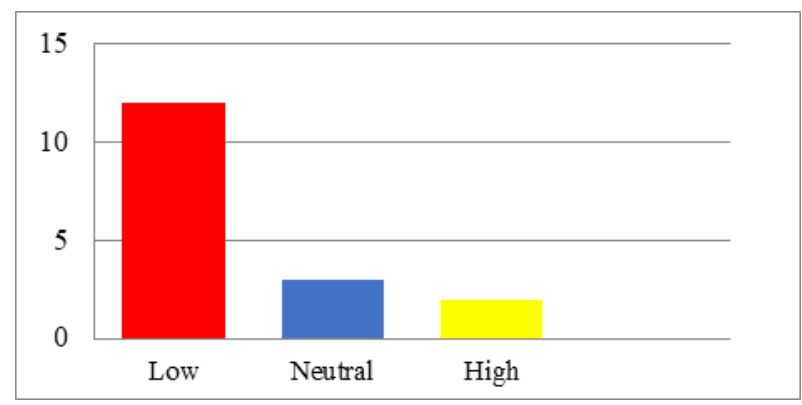

Fig. 2. Support, management, and operations dimension.

Participants strongly agree that if the leader can start planning, organizing, leading, and controlling the school's participant by using technology well, it can be affected by implementing digital leadership. Because, as a leader, someone should lead a school managerially. 


\section{E. Assessment and evaluation dimension}

The last aspects are about the assessment and evaluation dimension. The participants indicated possessed had low of digital leadership. Therefore, researchers can infer that most participants $(88 \%)$ agree that digital leadership was lower. Additionally, the teachers and the students stated that the teaching-learning instruction was still more inadequate; the staff's explanation also supported those management meetings that used technology were even shorter.

\section{CONCLUSION}

This research found that digital leadership in the process of teaching activities, productivity and professional practice dimension, management and process of evaluation during Pandemic Covid19 in MA Nurul Falah was lower. Therefore, it can be concluded that digital leadership contributes to the process of teaching-learning and school controlling. It also affected the operation of the government of that school. Thus, it can be inferred that a leader should enrich their digital skill to support the education system during Pandemic Covid19.

\section{ACKNOWLEDGMENTS}

The researcher would like to express the gratitude to Mr. Dr. Aceng Muhtaram for his patience guidance and advises to this research. This article is presented for The $4^{\text {th }}$ International Conference on Research of Educational Administration and Management (ICREAM) 2020.

\section{REFERENCES}

[1] National Board for Disaster Management. Report of Spread Covid-19 23 September 2020 [Internet]. Vol. p. Available from: https://covid19.go.id/p/berita/infografis-covid-19-23-september-2020

[2] U. Al Faruqi, Future Service in Industry 5.0. J Sist Cerdas. 02: 2. 2019.

[3] R.M. Hasan Hariria and MP, Leadership styles and decision-making styles in an Indonesian school context. Sch Leadersh Manag Former Sch Organ. 34, No. 3,(School leadership and management). 2014.

[4] G.N. Selyanskaya, K.V. Isaeva, D.Y. Busalov, "Fourth industrial revolution and management 3.0: Conditions for the transformation of higher education". Test Eng Manag. 82. 2020.

[5] M.S. Gençer, Y. Samur, "Leadership styles and technology: Leadership competency level of educational leaders". Procedia-Social and Behavioral Sciences, 229, pp.226-233. 2016.

[6] B. Yucebalkan, "Digital leadership in the context of digitalization transformation". Soc Behav Sci. 2020.

[7] D. Cecilio-Fernandes, M.C.R. Parisi, T.M. Santos, J. Sandars, "The COVID-19 pandemic and the challenge of using technology for medical education in low and middle income countries". MedEdPublish. 9(1). 2020 .

[8] K.D. Nguyen, T. Enos, T. Vandergriff, R. Vasquez, P.D. Cruz, H.T., Jacobe, and M.M. Mauskar, "Opportunities for education during the COVID-19 pandemic". Education. 2020.

[9] S.J. Daniel, "Education and the COVID-19 pandemic". Prospects. 2020.

[10] M. Rajab, A. Gazal, K. Alkattan, "Challenges to Online Medical Education During the COVID-19 Pandemic". Cureus. 2020.

[11] J.W. Creswell, Education Research. Fourth. Buchlotz M, editor. London: Pearson. 212. 2012. 